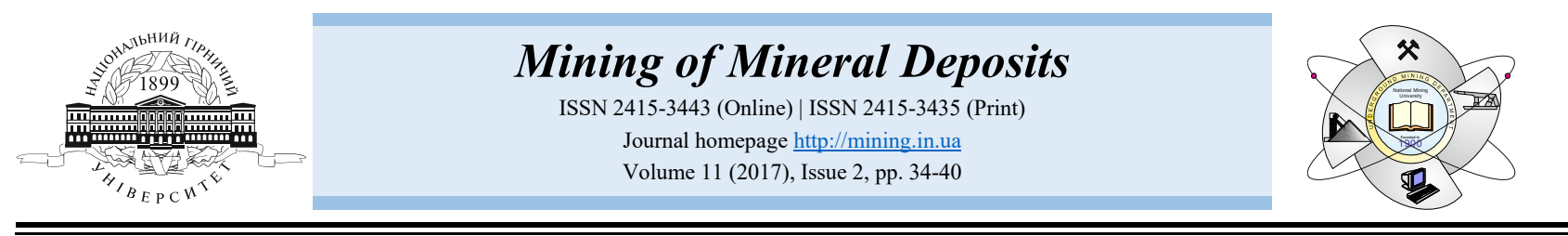

UDC 556:004.942+699.828

https://doi.org/10.15407/mining11.02.034

\title{
MODELING THE DRAINAGE FACILITIES OPERATION AT THE PROSPECTIVE CONSTRUCTION SITE ON THE DNIPRO FLOODLAND
}

\author{
V. Tymoshchuk ${ }^{1 *}$, Ye. Sherstiuk ${ }^{1}$, Z. Niedbalski ${ }^{2}$, T. Morozova ${ }^{3}$ \\ ${ }^{1}$ Hydrogeology and Engineering Geology Department, National Mining University, Dnipro, Ukraine \\ ${ }^{2}$ Faculty of Mining and Geoengineering, AGH University of Science and Technology, Krakow, Poland \\ ${ }^{3}$ Physics Department, National Mining University, Dnipro, Ukraine \\ *Corresponding author: e-mail vasyl.tymoshchuk@gmail.com, tel.+380567560961
}

\section{МОДЕЛЮВАННЯ РОБОТИ ДРЕНАЖНИХ СПОРУ Д НА ДІЛЯНЦІ ПРОЕКТОВАНОЇ ЗАБУ ДОВИ ЗАПЛАВИ РІЧКИ ДНІПРО}

\author{
В. Тимощук ${ }^{1 *}$, Є. Шерстюк ${ }^{1}, 3$. Нєдбальскі ${ }^{2}$, Т. Морозова ${ }^{3}$ \\ ${ }^{1}$ Кафедра гідрогеології та інженерної геологї̈, Національний гірничий університет, Дніпро, Украӥна \\ ${ }^{2}$ Факультет гірництва та геоінженерії, Краківська гірничо-металургійна академія ім. С. Сташиия, Краків, Польща \\ ${ }^{3}$ Кафедра фізики, Національний гірничий університет, Дніпро, Україна \\ *Biдповідальний автор: e-mail vasyl.tymoshchuk@gmail.com, тел. +380567560961
}

\begin{abstract}
Purpose. To carry out predictive assessment of the hydrodynamic regime at the prospective construction site on the Dnipro floodland in order to choose an expedient drainage system and substantiate the drainage parameters.

Methods. In studying the hydrodynamic regime, we used the method of variant modeling of three-dimensional filtration processes during the operation of various types of drainage and different drainage element layouts using a numerical mathematical model implemented on the basis of a finite differences method.

Findings. The main mode-forming factors of the investigated territory have been determined using the results of analysis and generalization of the data related to geological structure and hydrogeological conditions. The general hydrodynamic scheme of the simulated area has been developed, the structure of geofiltration model has been justified, its initial and boundary conditions have been determined. Predictive estimation of groundwater level regime has been executed, comparative analysis of vertical and bed drainage efficiency with various schemes of drainage element layouts has been carried out by simulation. The efficiency of the drainage structures operation in the protected area has been estimated for high-level flood conditions with $1 \%$ probability in the Dnipro.
\end{abstract}

Originality. Patterns in the hydrodynamic regime formation of the Dnipro floodland have been determined under the influence of the main mode-forming factors in conditions of drainage operation.

Practical implications of the work consist in substantiation of choosing the hydrodynamically expedient drainage system, the layout of dewatering constructions and drainage parameters for the site of the projected construction. The results of this research can form the basis for the development of the protective engineering measures in construction design at sites within potentially flooded river valleys.

Keywords: hydrodynamic regime, geofiltrational simulation, groundwater regime prediction, drainage system, parameters of drainage dewatering

\section{INTRODUCTION}

Current rates of urban development and increase in real estate cost are determining the necessity of using new areas for construction, where engineering geological and hydrogeological conditions require additional engineering solutions to protect building and construction (Sliusarenko, Shuminskyi, Tytarenko, Khlapuk, \& Shapoval, 2016; Shubin \& Shubin, 2010).
Thus, when designing a sports complex in Dnipro city on the alluvial sediments of the Dnipro in conditions of actual hydraulic interrelationship between the river and the groundwaters, it is necessary to substantiate the choice of a drainage system and predict changes in the groundwater regime.

Geological cross-section of the prospective construction site is represented by a complex of Modern, UpperMiddle Quaternary oxbow and alluvial sediments, that 
are underlaid by the weathering crust of PaleozoicCenozoic rocks. On the surface, bedrock is covered by technogenic soils. The site is characterized by the development of a quaternary aquifer which is bounded by the Dnipro. The stable level of groundwater was observed (August 2016) at depths 1.30 to $5.30 \mathrm{~m}$ from the surface (absolute elevations 51.29 to $51.50 \mathrm{~m}$ ). The hydrodynamic regime of the aquifer is closely related to the level regime of the river waters. The investigated site is classified as a naturally and permanently flooded area.

In this regard, there is an important task to forecast changes in hydrodynamic regime in the area of the prospective construction for backup groundwater conditions corresponding to the Dnipro 1\% probability flooding and substantiate rational parameters of drainage dewatering.

The object of the research is geofiltration processes in the floodland area of the Dnipro middle flow in geological and hydrogeological conditions disturbed by construction and operation of the designed facilities.

Two cases of drainage system have been considered in the study: the bed drainage (horizontal) and the vertical one.

Bed drainage is a part of preventive measures for protecting individual buildings and structures from flooding (Barinova, 1991; Valipour, 2012). Drainages are created, as a rule, during the construction period and prevent the rise of the groundwater level under the protected facilities. They reduce additional infiltration into groundwater by interception and diversion of leaks. The use of bed drainages is advisable in low-permeable soils.

Vertical drainage in the form of a series or group of wells is used when a horizontal drainage application is economically inexpedient, or, when the high building density of the flooded area and its saturation with engineering communications makes it difficult or even impossible (Barinova, 1991; Valipour, 2012). Such drainage is advisable to apply in high permeability sediments $(k>5.0 \mathrm{~m} /$ day $)$, when the thickness of watered sediments is over several meters and the depth of the aquiclude more than $8.0-10.0 \mathrm{~m}$. It can also be used in case of a two-layered structure of the watered strata, when the upper layer is composed of low-permeable clayey rocks with several meters thickness, and the lower one - of high-permeable rocks with a multilayered structure of watered strata of considerable $(>10.0 \mathrm{~m})$ thickness.

\section{MODELING}

To assess changes in the hydrodynamic regime at the site of the prospective construction, we used a numerical model of geofiltration that approximates a threedimensional groundwater flow with constant density in a porous medium, implemented in the MODFLOW 2009.1 software package. The flow model is described by the partial differential equation:

$$
\frac{\partial}{\partial x}\left(k_{x x} \frac{\partial h}{\partial x}\right)+\frac{\partial}{\partial y}\left(k_{y y} \frac{\partial h}{\partial y}\right)+\frac{\partial}{\partial z}\left(k_{z z} \frac{\partial h}{\partial z}\right)+W=S_{S} \frac{\partial h}{\partial t}
$$

where:

$k_{x x}, k_{y y}, k_{z z}$-hydraulic conductivities in directions of coordinate axes $X, Y$ and $Z(\mathrm{~L} / \mathrm{T})$;

$h$-potentiometric water head function (L);
$W$ - flow $\left(\mathrm{T}^{-1}\right)$ rate per unit: for inflow $W>0$, for outflow $-W<0$;

$S_{s}-$ specific storage of porous environment $\left(\mathrm{L}^{-1}\right)$;

$t$ - time (T).

Equation (1), together with the boundary and initial conditions, describes a three-dimensional transient groundwater flow in a heterogeneous and anisotropic medium, provided that the main directions of the hydraulic conductivities coincide with the directions of the coordinate axes (Shestakov, 2009; Kinzelbach, 1986; Visual MODFLOW..., 2009).

The computational mapping of the construction site was done considering the peculiarities of the area geological structure, the character of the aquifer occurrence and its hydraulic features, filtration properties of rocks, specifics of aquifer recharge and discharge in the area of its development and along its lines.

The simulated area is defined within the boundaries of the main geomorphological elements and components of hydrographic network (Fig. 1), with dimensions of $760 \mathrm{~m}$ along the $x$-axis (in the sub-meridional direction) and $840 \mathrm{~m}$ along the $y$-axis (in the sub-latitudinal direction), with a total area of $0.64 \mathrm{~km}^{2}$. The dimensions of grid blocks are assumed to be $10 \times 10 \mathrm{~m}$. In accordance with geological framework of the area and the character of the quaternary aquifer occurrence, the model has a three-layer structure, composed of water-permeable sediments (Fig. 2):

1 layer - technogenic soils, a mixture of loams, sands, soil and construction debris, also oxbow light sandy loams, silty sandy loams with sand interlayers, with the thickness from 4.00 to $16.70 \mathrm{~m}$;

2 layer - Upper-Middle Quaternary fine, medium, heterogeneous alluvial sands, with the thickness $3.1-6.4 \mathrm{~m}$;

3 layer-Middle Quaternary heterogeneous alluvial sands, with inclusions of gravel, gruss, and pebbles with the thickness of $2.71-6.90 \mathrm{~m}$, deposited on protogenic kaolin acting as a relative aquiclude.

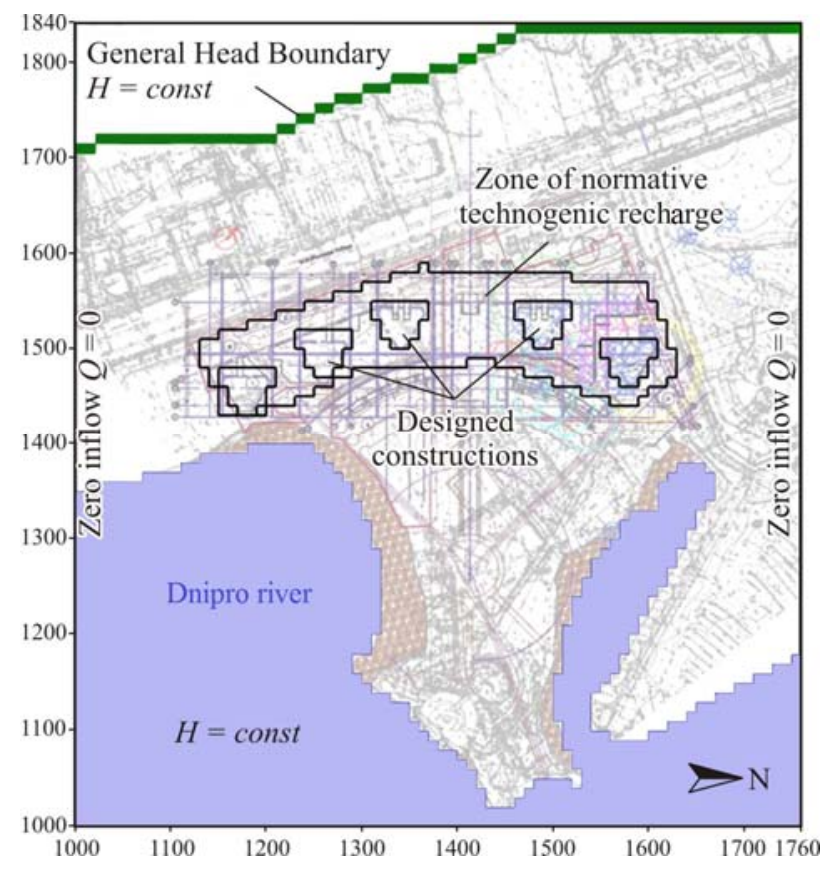

Figure 1. Hydrodynamic scheme of simulated area 
a

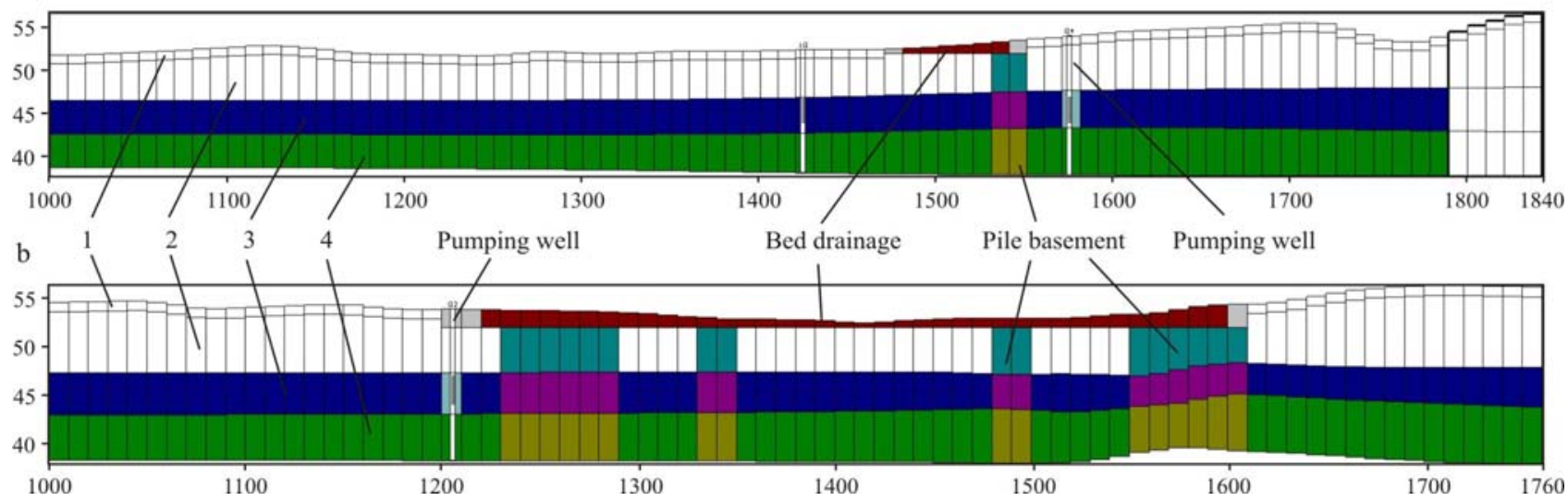

Figure 2. Model structure in cross-section: (a) sub-meridional direction; (b) sub-latitudinal direction; 1, 2, 3, 4-calculated layers

As an external hydrodynamic boundary on the western outline of the model, we took the remote boundary with constant infiltration ( $H=$ const) whose position is set according to the general hydrodynamic layout of the territory. The head value on this boundary is assumed to be $54.0 \mathrm{~m}$, which corresponds to the established occurrence of the Quaternary aquifer (according to the data from Dnipro State Company of Engineering and Technical Survey for Construction) within the interval of junction between the flood plain and the bedrock slope with absolute elevations 53.16 - 54.96 m (Fig. 1).

The values of hydraulic conductivities on the remote infiltration boundary are set according to their filtration properties and vary from 0.056 to $0.096 \mathrm{~m}^{2} /$ day for technogenic soils (layer 1) and 0.245 to $0.327 \mathrm{~m}^{2} /$ day for fine sands (layer 2), and up to 0.653 to $0.736 \mathrm{~m}^{2} /$ day for heterogeneous gravel sands at the bottom of the aqueous stratum (layer 3).

Departing from the character of the aquifer recharge and discharge and the general direction of the flow from the bedrock slope to the river, we assigned the boundary condition of the second order on the outer northern and southern boundaries of the model, corresponding to the absence of a lateral inflow $-Q=0$. The Dnipro is the outer hydrodynamic boundary along the eastern contour, its water level determined by the operation modes of Dnipro Hydro Power Plant (HPP) and water reservoirs up the river.

At an absolute elevation of the normal headwater elevation (NHE) of $51.40 \mathrm{~m}$, the amplitude of the water level fluctuation does not exceed $0.36 \mathrm{~m}$ near the Dnipro city with daily regulation at Dniprodzerzhynska HPP, while the maximum and minimum possible elevations are $51.84 \mathrm{~m}$ and $50.52 \mathrm{~m}$, respectively.

When solving inverse problems and evaluating the model's convergence, the absolute elevation of water in the Dnipro was adopted according to the period of engineering-geological survey in August 2016, which corresponds to the summer-autumn period of low water $51.00 \mathrm{~m}$. In predictive calculations, the water level in the river was set equal to the value of the NHE $-51.40 \mathrm{~m}$, and in assessing the efficiency of the drainage systems to the absolute level of $1 \%$ probability flood $-52.68 \mathrm{~m}$ (according to the data from "UkrGidroproekt").

The hydraulic conductivity of the Dnipro riverbed is determined in accordance with the filtration properties of the soils for calculated layers 1 and 2 within the riparian section of the river bed and is assumed to be $250 \mathrm{~m}^{2} /$ day.

Infiltration recharge in the model is set at $15.7 \mathrm{~mm} /$ year, which is about $3 \%$ of the total amount of atmospheric precipitation which is $522 \mathrm{~mm} /$ year according to the National Construction Standard DSTU-N B V.1.1-27:210. In assessing natural infiltration recharge, the research data, obtained by Grinevskiy and Novoselova (2010) for the Black Sea artesian basin have been taken into account. In order to consider ground waters evaporation and seepage in the transient regions, we introduced a parameter ensuring reflux of underground waters within the lines where the depth of their occurrence does not exceed $50 \mathrm{~cm}$. Evaporation value in the model is assumed to be $495 \mathrm{~mm} /$ year, which corresponds to the value of evapotranspiration for a given climatic zone.

The modeling technique included the solution of inverse and predictive problems to assess the changes in the hydrodynamic regime at the construction site in accordance with the spatial location of the designed facilities, both in existing conditions and in conditions disturbed by the prospective construction.

Main factors determining hydrodynamic regime within the site of the projected construction were the change in recharge intensity due to leakages from water-supply and sewage facilities, the barrage effect created by pile basement construction, and the Dnipro water level changes.

The normative value of man-made infiltration recharge for urban areas with the appropriate type of construction in conditions of unstable moistening is $2.3 \cdot 10^{-3} \mathrm{~m} /$ day or $839.5 \mathrm{~mm} /$ year (Barinova, 1991).

In order to consider the barrage effect of pile basements, hydraulic conductivity values in the first and second layers were reduced by an order of magnitude within the contours of the designed buildings - to the depth corresponding to the foundation bed.

The effect of the Dnipro level regime in predictive calculations has been assessed for the case of maintaining the water level at the normal headwater elevation (NHE) $H=51.40 \mathrm{~m}$ and in conditions when the water level in the river reached the elevation of $1 \%$ probability $-H=52.68 \mathrm{~m}$.

A comparative analysis of drainage systems operation was carried out for the situation of steady-state groundwater flow with a combined effect of all the above factors and the water level in the Dnipro at $52.68 \mathrm{~m}$. 


\section{RESULTS}

Assessment of hydrodynamic regime on the prospective construction site in conditions present in August 2016 has been performed according to the data resulting from the solution of inverse problems in the steady-state formulation. The calculated groundwater levels for existing conditions on the construction site are in the range of $51.20-51.55 \mathrm{~m}$ with actual values of their occurence at $51.29-51.50 \mathrm{~m}$, with a deviation of calculated and actual levels not exceeding $0.20 \mathrm{~m}$.

Convergence of the calculated data with actual observation data estimated during the model calibration is characterized by a correlation coefficient of 0.78 with a standard error of $0.033 \mathrm{~m}$, which confirms the problem formulation correctness and reliability of predictive calculations.

In solving predictive problems, the water level in the Dnipro was determined by a normal headwater elevation (NHE) of $51.40 \mathrm{~m}$, which, due to hydraulic interrelation, ensures a corresponding groundwater dam at the prospective construction site. Assessment of the barrage effect of pile basement related to the decrease in permeability of soils in the foundations of the designed buildings, testified that ten-fold reduction of soil hydraulic conductivity in the area of piling does not result in significant deformation of underground water surface. Rising of underground water occurs directly in the contours of the designed buildings and does not exceed $3-5 \mathrm{~cm}$.

In conditions of technogenic infiltration specified for the construction site at the value $W_{t}=855 \mathrm{~mm} /$ year, a groundwater dome is formed with the surface absolute elevations of $51.60-52.25 \mathrm{~m}$. In this case, the barrage effect of pile basement is stronger: within the "building footprint"; the groundwater level rises to $20 \mathrm{~cm}$, which corresponds to the absolute elevation of about $52.40 \mathrm{~m}$.

When the water level in the Dnipro rises to the elevation of $52.68 \mathrm{~m}$, the predicted groundwater level at the construction site reaches the elevation of $52.80-$ $53.00 \mathrm{~m}$, which is equivalent to groundwater afflux by $1.10-1.30 \mathrm{~m}$.

Changes in hydrodynamic regime of the alluvial aquifer associated with the Dnipro water level rise to the elevation of $52.68 \mathrm{~m}$ are related to the sharp increase of its recharge with the river water, which is proved by the distribution of balance constituents of the region.

Thus, in conditions of the present occurrence of underground waters, the modeled site receives $66.3 \mathrm{~m}^{3} /$ day as recharge from the river and loses $176.9 \mathrm{~m}^{3} /$ day as discharge into the river. In flood conditions, these balance constituents are $316.4 \mathrm{~m}^{3} /$ day and $49.6 \mathrm{~m}^{3}$ /day correspondingly.

The complex effect of the factors influencing the hydrodynamic regime of underground waters within the site of the prospective construction leads to the increase of groundwater levels by the value up to $1.80 \mathrm{~m}$, which results in flooding and partial inundation of the studied area.

While substantiating the choice of an expedient drainage system to protect the construction site from flooding and inundation in flood periods, a bed drainage and vertical drainage with variants of dewatering wells placement have been taken into consideration.

In determining the elevation of the necessary underground water level maintenance in the protected area, the following parameters have been taken into account: the basement floor elevation $(53.70 \mathrm{~m})$, the actual position of groundwater level $(51.29-51.50 \mathrm{~m})$ and the values of its seasonal variation $(0.50-1.10 \mathrm{~m})$, the elevation of the capillary rise ( $0.35 \mathrm{~m}$ for fine sands), and seasonal freezing depth $(0.96 \mathrm{~m})$. The absolute elevation of groundwater level equal to $52.40 \mathrm{~m}$ has been used as a criterion for the necessary dewatering.

Each predictive variant considered the impact of additional technogenic recharge caused by leakages from water-supply and sewage facilities, as well as the barrage effect of pile basements. Drainage operation forecasting was performed for conditions of the flood in the Dnipro with $1 \%$ probability, with a water level of $52.68 \mathrm{~m}$.

The bed drainage has been simulated by specifying an additional calculated layer with increased hydraulic conductivity $K_{X}=K_{Y}=100.0 \mathrm{~m} /$ day, $K_{Z}=10.0 \mathrm{~m} /$ day, contour drains with a conductivity of $300 \mathrm{~m}^{2} /$ day and a drainage bottom at the elevation of $52 \mathrm{~m}$.

Vertical drainage has been simulated by specifying a system of pumping wells along the site contour, with the well screen in the interval of elevations $44-47 \mathrm{~m}$ within the second layer. Two schemes of dewatering - with 13 and 5 pumping wells with a flow rate of $1.5 \mathrm{~m}^{3} /$ hour and $5.0 \mathrm{~m}^{3} /$ hour, respectively, have been considered. The total water intake of drainage in the first case was $468.0 \mathrm{~m}^{3} /$ day, in the second $-600.0 \mathrm{~m}^{3} /$ day.

Modeling has shown that the safe groundwater level is achieved directly within the construction site when the bed drainage is functioning (Fig. 3), while the necessary lowering of the levels is ensured by filtration layer at $52 \mathrm{~m}$ and the amount of drainage water intake $307.6 \mathrm{~m}^{3} /$ day. The required water level reduction within the contours of the construction site is achieved when the hydraulic conductivity of filtering material is not less than $100.0 \mathrm{~m} /$ day.

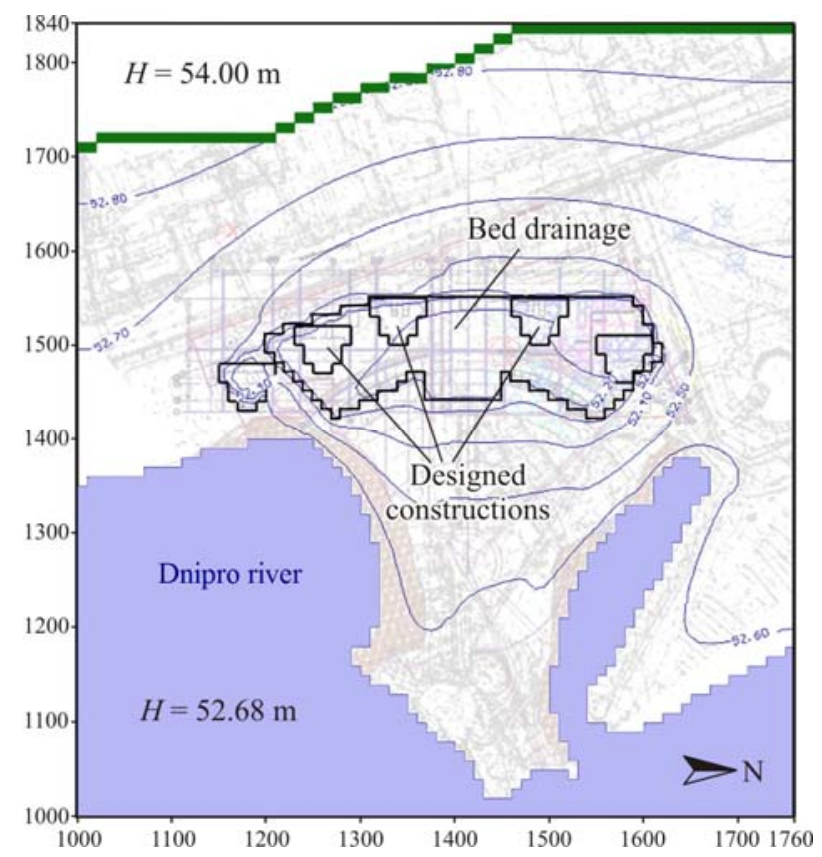

Figure 3. Groundwater surface in conditions of bed drainage operation 
Under conditions of vertical drainage with 13 pumping wells, the groundwater level in the alluvial aquifer is reduced not only within the construction site but also in adjacent areas within the $60-80$-meter contour. Water table reduces to level $52.40 \mathrm{~m}$ at the protected construction site when its elevation in the dewatering wells is at $52.12-52.25 \mathrm{~m}$. The growth of hydraulic depression in the alluvial aquifer leads to increasing the proportion of inflow resources from the Dnipro in the hydraulic balance of the simulated area.

In the variant of vertical drainage with 5 pumping wells, the required safe water level reduction in the alluvial aquifer is achieved while the water level in dewatering wells drops to $51.33-51.97 \mathrm{~m}$, which causes the development of hydraulic depression in the aquifer with level decrease to $52.40 \mathrm{~m}$ and lower beyond the construction site within 100 - 120-meter contour (Fig. 4).

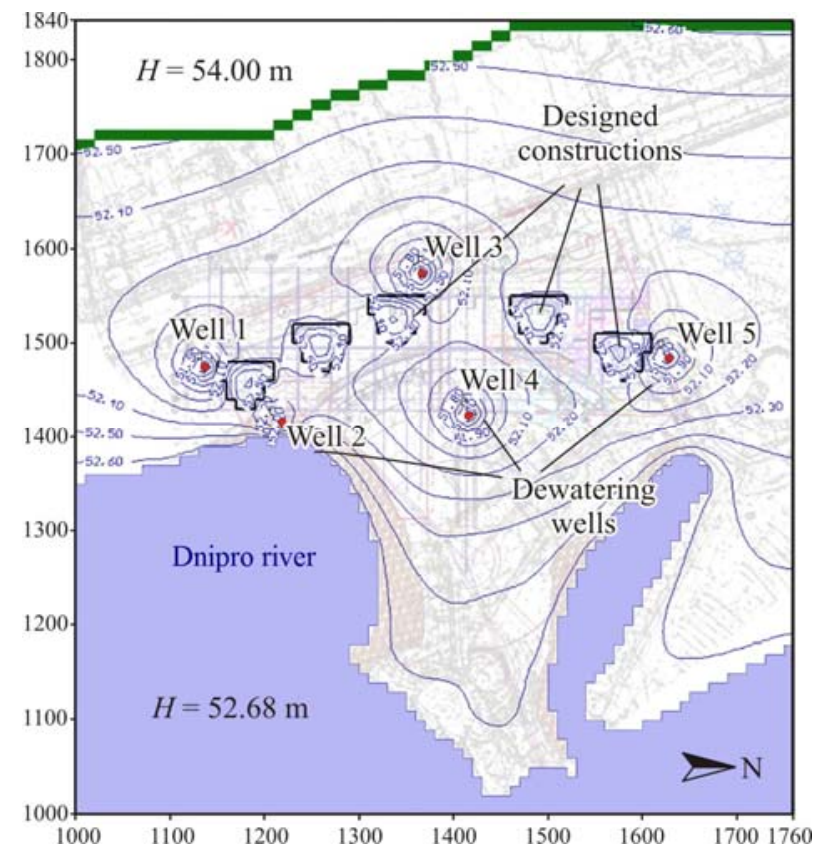

Figure 4. Groundwater surface in conditions of vertical drainage operation (5 wells)
Similar to the case of 13 pumping wells, the hydrodynamic balance of the simulated area is characterized by the increased share of inflow component in the balance formed due to the river.

A comparative analysis of drainage facilities operation has shown that the efficiency of bed drainage functioning is ensured when the sole of filtering material is laid at elevations of not more than $52 \mathrm{~m}$, which significantly limits the effect of bed drainage on adjacent areas.

Vertical drainage ensures a deeper dewatering level so that its efficiency can be achieved with fewer water intake facilities (Fig. 5).

At the same time, due to the growth of hydraulic depression, the effect of vertical drainage will extend to the adjacent areas which are also susceptible to flooding and inundation during the flood periods.

The drainage parameters for the operation of 5-wells dewatering system with a total flow rate of $25 \mathrm{~m}^{3} /$ hour have been estimated for a flood of up to 120-day duration with an absolute water level of $1 \%$ probability $52.68 \mathrm{~m}$. Figure 6 shows graphs of the change in the calculated groundwater levels of the alluvial aquifer in the central part of the site. According to the calculated data, 15 days after the flood beginning, groundwater levels in the central part of the site will exceed the permissible mark of $52.40 \mathrm{~m}$ and will continue to grow. The maximum elevation of the groundwater, which can be reached, is $52.90-52.93 \mathrm{~m}$.

After the end of the flood period (90 days), the recovery of the levels below the safe level of $52.40 \mathrm{~m}$ will take 30 days. Hence the period when groundwater levels in the protected area are above the permissible level is 100 to 105 days, which determines the interval of the water drainage system operation.

Water table drops to the permissible level of $52.40 \mathrm{~m}$ in the central part of the investigated site in $1-5$ days after starting the vertical drainage system of 5 pumping wells with a total flow rate of $25 \mathrm{~m}^{3} /$ hour, and is maintained within the safe level range of $52.10-52.40 \mathrm{~m}$ during the entire time of spring flood.

a

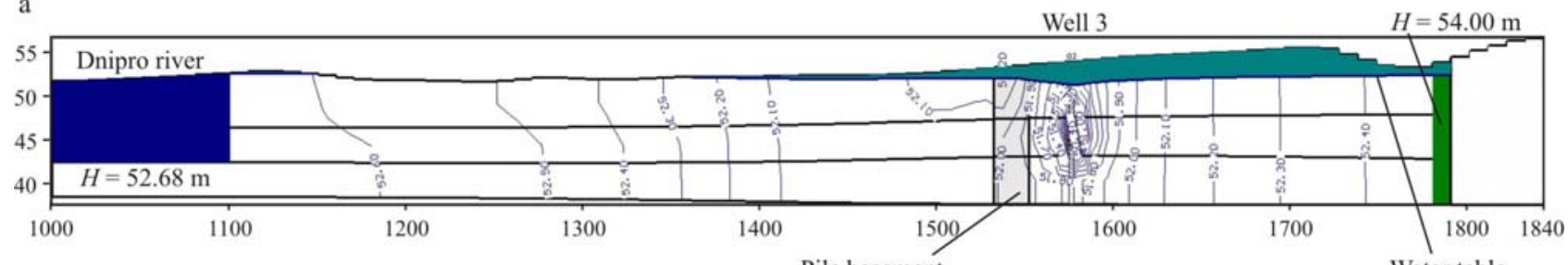

bell 1

Pile basement

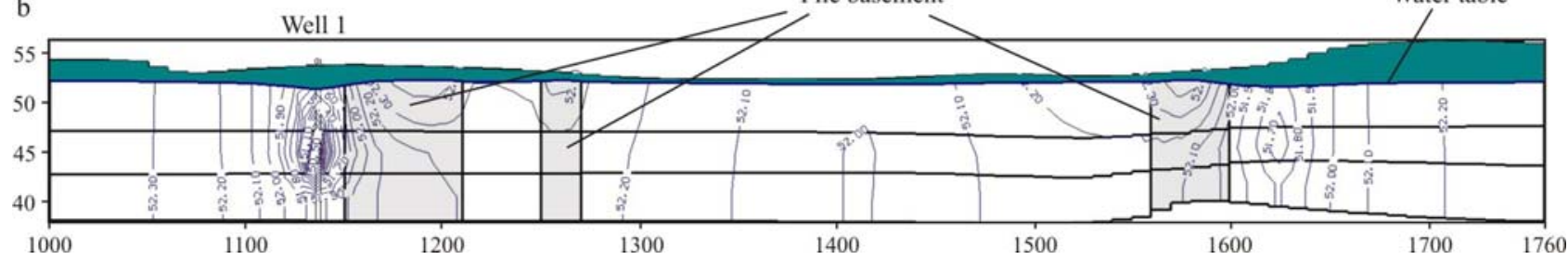

Figure 5. Hydrodynamic cross-section for the case of 5 dewatering wells operation: (a) sub-meridional direction; (b) sub-latitudinal direction 


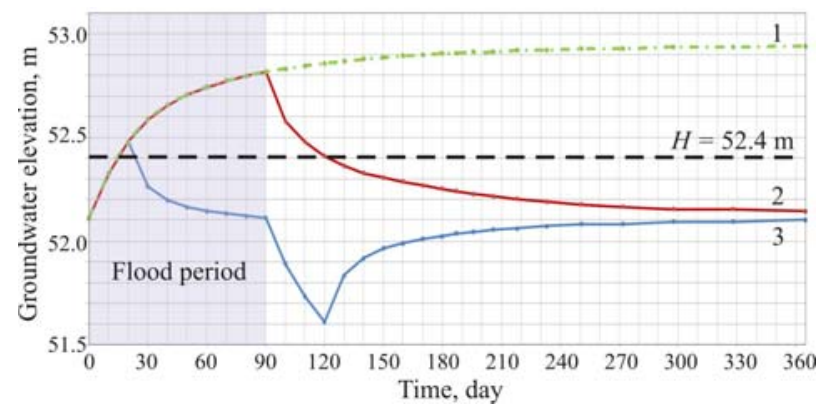

Figure 6. Forecast of groundwater level dynamics during the high water period; 5 dewatering wells are working: 1 -water table rise during flood; 2 - level recovery after flood; 3 -dewatering wells operation

\section{CONCLUSIONS}

Analysis of geological and hydrogeological conditions of floodland territory in the middle reaches of the Dnipro has shown that the main factors affecting the hydrodynamic regime in the floodland areas under construction are the changes in recharge intensity due to leakages from water-supply and sewage facilities, the barrage effect of pile basements of the designed buildings, and the level regime of the river; the latter being determinant in conditions of alluvial aquifer regime disturbed by the construction.

The predictive moodeling of hydrodynamic regime in the prospective building site allowed to conclude that the spring flood in the Dnipro with a water level increase to $52.68 \mathrm{~m}$ corresponding to $1 \%$ probability, leads to groundwater level increase at the construction site to absolute elevations of $52.80-53.00 \mathrm{~m}$, which corresponds to water table afflux by $1.10-1.30 \mathrm{~m}$.

In these conditions, the vertical drainage in contrast to the bed drainage provides deeper dewatering, whereby the efficiency of its operation can be achieved with fewer water intake facilities. In this case, the drainage effect will spread to the adjacent areas, which are also susceptible to flooding and inundation during the flood periods, due to development of a deeper hydraulic depression.
Assessing the vertical drainage operation in conditions of unsteady filtration regime, it was found that during the Dnieper flood period, groundwater levels in the central part of the construction site can reach the altitude of $52.90-52.93 \mathrm{~m}$ in only 15 days after the flood beginning.

In these conditions, water table drops to the permissible level of $52.40 \mathrm{~m}$ in $1-5$ days after the start of the vertical drainage system of 5 pumping wells with a total flow rate of $25 \mathrm{~m}^{3} /$ hour, and is maintained within the safe level range during the entire time of spring flood.

\section{ACKNOWLEDGEMENTS}

The research was carried out with the technical support of the specialists of LLC "VODOPROEKT".

\section{REFERENCES}

Barinova, I. (1991). Prognozy podtopleniya i raschet drenazhnykh sistem na zastraivayemykh $i$ zastroyennykh territoriyakh. Moskva: Stroyizdat.

Grinevskiy, S., \& Novoselova, M. (2010). Zakonomernosti formirovaniya infil'tratsionnogo pitaniya podzemnykh vod. Vodnyye resursy, 37(6), 1-12.

Kinzelbach, W. (1986). Groundwater Modelling. Amsterdam: Elsevier.

Shestakov, V. (2009). Gidrogeodinamika. Moskva: KDU.

Shubin, M., \& Shubin, A. (2010). Issledovaniye protsessa podtopleniya zastroyennykh territoriy i razrabotka zashchitnykh meropriyatiy. Vestnik Volgogradskogo Gosudarstvennogo Arkhitekturno-Stroitel'nogo Universiteta, (17), 142-147.

Sliusarenko, Yu.S., Shuminskyi, V.D., Tytarenko, V.A., Khlapuk, M.M., \& Shapoval, V.H. (2016). Rozrobka DSTU-N B Inzhenernyi zakhyst terytorii, budivel i sporud vid pidtoplennia ta zatoplennia. Budivelni konstruktsii, 83(1), 206-216.

Valipour, M. (2012). A Comparison between Horizontal and Vertical Drainage Systems (Include Pipe Drainage, Open Ditch Drainage, and Pumped Wells) in Anisotropic Soils. IOSR Journal of Mechanical and Civil Engineering, 4(1), 7-12. https://doi.org/10.9790/1684-0410712

Visual MODFLOW 2009.1: User's Manual. (2009). Waterloo: Schlumberger Water Services.

\section{ABSTRACT (IN UKRAINIAN)}

Мета. Прогнозна оцінка гідродинамічного режиму підземних вод на ділянці перспективної забудови заплавної частини долини р. Дніпро у зв'язку з вибором доцільної системи дренажу та обгрунтуванням параметрів дренажного водозниження.

Методика. Дослідження гідродинамічного режиму варіантним моделюванням процесів планово-профільної фільтрації в умовах роботи різних видів дренажу та компоновки дренажних споруд із використанням чисельної математичної моделі, реалізованої на базі метода скінчених різниць.

Результати. Визначені основні режимоутворюючі фактори досліджуваної території, розроблена загальна гідродинамічна схема модельованої області й обгрунтована структура геофільтраційної моделі, визначені її початкові та граничні умови. За даними моделювання виконана прогнозна оцінка рівневого режиму підземних вод, проведено порівняльний аналіз ефективності пластового та вертикального дренажів при різних схемах компоновки водознижуючих споруд. Ефективність роботи дренажних споруд на території, що захищається, оцінена для умов проходження високого паводку при заданій забезпеченості рівня води у р. Дніпро.

Наукова новизна. Встановлення закономірностей формування гідродинамічного режиму підземних вод у заплавній частині долини р. Дніпро під впливом основних режимоутворюючих факторів в умовах роботи дренажного водозниження.

Практична значимість. Обгрунтування вибору гідродинамічно доцільної системи дренажу, схеми розташування водознижуючих споруд і параметрів дренажного водозниження на ділянці проектованого будівництва. Результати досліджень можуть складати основу для розробки інженерних заходів захисного характеру при проектуванні об'єктів будівництва в межах потенційно підтоплюваних заплавних ділянок долин річок. 
Ключові слова: гідродинамічний режим, геофільтраційне моделювання, прогноз рівневого режиму, система дренажу, параметри дренажного водозниження

\section{ABSTRACT (IN RUSSIAN)}

Цель. Прогнозная оценка гидродинамического режима подземных вод на участке перспективной застройки пойменной части долины р. Днепр в связи с выбором целесообразной системы дренажа и обоснованием параметров дренажного водопонижения.

Методика. Исследования гидродинамического режима вариантным моделированием процессов плановопрофильной фильтрации в условиях работы различных видов дренажа и компоновки дренажных сооружений с использованием численной математической модели, реализованной на базе метода конечных разностей.

Результаты. Определены основные режимообразующие факторы исследуемой территории, разработана общая гидродинамическая схема моделируемой области и обоснована структура геофильтрационной модели, определены ее начальные и граничные условия. По данным моделирования выполнена прогнозная оценка уровенного режима подземных вод, проведен сопоставительный анализ эффективности пластового и вертикального дренажей при различных схемах компоновки водопонизительных сооружений. Эффективность работы дренажных сооружений на защищаемой территории оценена для условий прохождения высокого паводка при заданной обеспеченности уровня воды в р. Днепр.

Научная новизна. Установлены закономерности формирования гидродинамического режима подземных вод в пойменной части долины р. Днепр под влиянием основных режимообразующих факторов в условиях работы дренажного водопонижения.

Практическая значимость. Обоснование выбора гидродинамически целесообразной системы дренажа, схемы расположения водопонизительных сооружений и параметров дренажного водопонижения на участке проектируемого строительства. Результаты исследований могут составлять основу для разработки инженерных мероприятий защитного характера при проектировании объектов строительства в пределах потенциально подтапливаемых пойменных участков долин рек.

Ключевые слова: гидродинамический режим, геофильтрационное моделирование, прогноз уровенного режима, система дренажа, параметры дренажного водопонижения

\section{ARTICLE INFO}

Received: 8 December 2016

Accepted: 15 May 2017

Available online: 30 June 2017

\section{ABOUT AUTHORS}

Vasyl Tymoshchuk, Candidate of Technical Sciences, Associate Professor of the Hydrogeology and Engineering Geology Department, National Mining University, 19 Yavornytskoho Ave., 1/54, 49005, Dnipro, Ukraine. E-mail: vasyl.tymoshchuk@gmail.com

Yevheniia Sherstiuk, Assistant Professor of the Hydrogeology and Engineering Geology Department, National Mining University, 19 Yavornytskoho Ave., 1/54, 49005, Dnipro, Ukraine. E-mail: eusherstuk@gmail.com

Zbigniew Niedbalski, Doctor of Philosophy, Deputy Dean of the Faculty of Mining and Geoengineering, AGH University of Science and Technology, 30 Adam Mickiewicz St, A-4/26, 30-059, Krakow, Poland, E-mail: niedzbig@agh.edu.pl

Tamara Morozova, Senior Instructor of the Physics Department, National Mining University, 19 Yavornytskoho Ave., 2/82a, 49005, Dnipro, Ukraine. E-mail: morozova.t.v@nmu.one 